Short Communication

\title{
Development of Composite Material Based on Porous Microfibrous Carbon and Zinc Oxide for Energy Storage Application
}

\author{
Youcef Guetteche ${ }^{1,2}$, Tarik Bordjiba ${ }^{1,{ }^{*}}$, Bilel Bouguerne ${ }^{l}$, Zineb Nabeti ${ }^{l}$, Ourida Mahmoudi ${ }^{1}$, \\ Ahcen Lemzademi ${ }^{1}$ \\ ${ }^{1}$ Laboratoire de Génie Electrique de Guelma (LGEG), Université 8 mai 1945 Guelma, Algeria \\ ${ }^{2}$ Université 20 Août 1955 Skikda, Algeria \\ *E-mail: bordjiba_tarik@yahoo.ca, bordjiba.tarik@univ-guelma.dz
}

doi: $10.20964 / 2017.03 .37$

Received: 4 November 2016 / Accepted: 11 January 2017 / Published: 12 February 2017

\begin{abstract}
The development of efficient energy storage devices is very important challenge for the progress of the renewable energy. One of the promising energy storage systems is the electrochemical capacitor. In this work, the composite material based on porous microfibrous carbon and zinc oxide by electrodeposition technique for electrochemical capacitor was synthetized and characterized. The formation mechanism of zinc oxide on porous microfibrouse carbon paper was proposed. This mechanism is constituted of three steps (i) production of $\mathrm{OH}^{-}$ions, (ii) creation of zinc hydroxide $\mathrm{Zn}$ $(\mathrm{OH})_{2}$, (iii) transformation of zinc hydroxide $\mathrm{Zn}(\mathrm{OH})_{2}$ to zinc oxide $\mathrm{ZnO}$. The composite materials based on a porous microfibrouse carbon paper and zinc oxide were studied by cyclic voltammetry and the electrochemical impedance. The synthesized electrodes show a good capacitive behavior. The electrodeposition time of 60 minute allows the formation of excellent electrode for electrochemical capacitor.
\end{abstract}

Keywords: Energy storage; electochemical capacitor; zinc oxide; porous carbon

\section{$\underline{\text { FULL TEXT }}$}

(C) 2017 The Authors. Published by ESG (www.electrochemsci.org). This article is an open access article distributed under the terms and conditions of the Creative Commons Attribution license (http://creativecommons.org/licenses/by/4.0/). 